\title{
Error Analysis of The Spoken English of The First Semester Students of Arabic Education of IAI DDI Polewali Mandar
}

\author{
Nur Afiah \\ Institut Agama Islam DDI Polewali Mandar, Sulawesi Barat \\ e-mail: nurafiah@ddipolman.ac.id
}

\begin{abstract}
The preliminary research focused on finding out the types of errors committed by the first semester students of Arabic Education of IAI DDI Polewali Mandar. The source of data was the spoken English of self introduction during the English subject. The aims was to analyze some error committed. The errors found from the data: the use of auxiliaries, tenses, prepositions, pronouns, plurals, error in pronunciation and some difficult words, phrase, sentence of the spoken English in during English subject of the Arabic Education of IAI DDI Polewali Mandar. The result of the research were used to decided students'needs and abilty of English on preparing the teaching material that were given in the first semester of 2010/2020 academic year.
\end{abstract}

Keywords: Error Analysis, Spoken English

\begin{abstract}
Abstrak
Penelitian pendahuluan ini berfokus untuk mencari tahu jenis kesalahan yang dilakukan oleh mahasiswa semester pertama Pendidikan Bahasa Arab di IAI DDI Polewali Mandar. Sumber data adalah ucapan lisan bahasa Inggris saat dari memperkenakan diri dalam mata kuliah Bahasa Inggris. Tujuannya adalah untuk menganalisis beberapa kesalahan yang dilakukan. Kesalahan ditemukan dari data: penggunaan kata bantu (auxiilaries), tenses, preposisi, kata ganti, bentuk jamak, kesalahan dalam pengucapan dan beberapa kata-kata sulit, frasa, kalimat bahasa Inggris yang diucapkan selama pertemuan pertama pada mata kuliah pelajaran Bahasa Inggris mahasiswa Pendidikan Bahasa Arab di IAI DDI Polewali Mandar. Hasil penelitian digunakan untuk menyusun dan menyiapkan bahan ajar berdasarkan kebutuhan siswa dan kemampuan dasar bahasa Inggris pada semester pertama tahun akademik 2019/2020.
\end{abstract}

Kata Kunci: Analisis Kesalahan, Ungkapan Lisan Berbahasa Inggris 


\section{Introduction}

Error analysis is an invaluable source of information to teachers. It provides information on students' errors which in turn helps teachers to correct students' errors and also improves the effectiveness of their teaching. Error analysis has been conducted to identify strategies which learners use in language learning, to track the causes of learner's errors, obtain information on common difficulties in language learning or on how to prepare teaching materials ${ }^{1}$. Similarly, Michaelides states that the systematic analysis of student's errors can be of great value to all those concerned, i.e., teachers, students and the researchers. For teachers it can offer clear and reliable picture of his students' knowledge of the target language ${ }^{2}$. Willcott conducted an error analysis to discover some of the problems that native speakers of Arabic had with the syntax of written English ${ }^{3}$. Both of them has the same point of view that error can be a helpful information not only for teacher and students but also researcher.

In another study, Scot and Tucker examined the errors generated by 22 Arab students enrolled in the first semester of a low-intermediate intensive English course at the American University of Beirut with the purpose of describing the approximated system and identifying the source and type and frequency of the generated errors ${ }^{4}$. Moreover, El- Sayed revealed that the subjects of his study generated 1140 errors: 640 errors were verbs and verbals, 159 errors in pronouns, 143 in articles and the rest were nouns, prepositions and adjectives ${ }^{5}$. The researcher found typically and requently some errors on students English class.

Karma and $\mathrm{Hajjaj}^{6}$ and also Farhat $^{7}$ attribute many of the article errors to mother tongue interference. Moreover, Belhhaj investigated the errors his students generated in the translation papers. The result showed verb formed tense errors, relative clause, adjective errors, preposition errors, noun errors, articles errors and miscellaneous ${ }^{8}$. In another study, Radwan examined the types of grammatical and lexical errors in the nominal group. The result showed that the errors made in the use of articles had the highest percentage ${ }^{9}$.

Dessouky found that similar errors occur in all levels of these subjects, but the difference was in the frequency of their occurrence ${ }^{10}$. Likewise, Farhat found similar types of

\footnotetext{
${ }^{1}$ Richards, J.C., "Social Factors, Interlanguage and Language Learning”, in Richards, J.C. (Ed.) Error analysis. Perspectives on Second Language Acquisition, (London: Longman, 1974).

${ }^{2}$ Michaelides, N.N., "Error Analysis: An Aid to teaching", English Teaching Forum, Vol. XXXVIII, No. 4, 1990.

${ }^{3}$ Willcott, P.J., "An Analysis of The Written English of Native Speakers of Arabic As Found in American History Final Examination Given at The University of Texas at Austin", (Unpublished Dissertation; USA: The University of Texas at Austin, 1972).

${ }^{4}$ Scott, M. S. and Tucker, G.R., "Error Analysis and English-Language Strategies of Arab Students". Language Learning, Vol. 24, No. 1, 1974.

${ }^{5}$ El-Sayed, A.M.M., "An Investigation into the Syntactic Errors of Saudi Freshmen's English Compositions". (Unpublished Dissertation; USA: Indiana University of Pennsylvania, 1982).

${ }^{6}$ Karma, N. and Hajjaj, H., Errors in English among Arabic Speakers Analysis and Remedy, (London: Longman, 1989).

${ }^{7}$ Farhat, S.H., "Error Analysis: A study of the Written Performance of University of Khartoum Freshmen". (Unpublished Thesis; Sudan: Khartoum University, 1994).

8 Belhaj, A.M., "Contrastive Textual Analysis: An Arabic-English, English-Arabic Translation Corpus". Occasional Papers. Vol. 24-25, 1997.

${ }^{9}$ Radwan, M.A., "A linguistic analysis of the grammatical and Lexical Errors in the Nominal Group Found in the Written English of Syrian University Students”. (Unpublished Dissertation; UK: University of Nottingham, 1988).

10 Dessouky, S.S., "Error Analysis: A no-stop Area of Research. An Analytical Study of English Verb and Preposition Errors in the Written Expression of Al-Azhar Students". Studies in Curricula and Methodology, No. 8, July, 1990.
} 
errors generated by his Sudanese students but with different order and frequency of occurrence $^{11}$.

The study of errors themselves without proper analysis would have been misleading. The number of correct responses gives a good picture of which items are being mastered and which are not. Therefore, this study hopes to enlighten teachers on the errors that require remedial work so that time is not wasted on teaching grammar items which pose little or no problems to the majority of the students in relation to speaking skill.

One of the main aims of error analysis is to help teachers assess more accurately what remedial work would be necessary for English as a Foreign Language (EFL) students preparing for an English Language test, so as to help students avoid the most common errors. Corder also held the same view regarding the function of error analysis and that there are two justifications for studying learners' errors: its relevance to language teaching and the study of the language acquisition process. It is appropriate to define what is meant by errors. The terms 'mistake' and'error' are often used interchangeably. However, there is a clear difference between the two ${ }^{12}$. The following definitions of 'errors' and 'mistakes' are applicable to this study. Norrish made a clear distinction between errors and mistakes. He postulated that errors are "a systematic deviation when a learner has not learnt something and consistently gets it wrong." He added that when a learner of English as a second or foreign language makes an error systematically, it is because he or she has not learnt the correct form. Norrish defined mistakes as "inconsistent deviation." When a learner has been taught a certain correct form, and he uses one form sometimes and another at other times quite inconsistently, the inconsistent deviation is called a mistake ${ }^{13}$.

Systematically, analysing errors made by language learners makes it possible to determine areas that need reinforcement in teaching ${ }^{14}$. Error analysis is a type of linguistic analysis that focuses on the errors learners make. It consists of a comparison between the errors made in the Target Language (TL) and that Target Language itself. In the article titled, "The significance of Learner Errors" Corder observed that Error analysis (EA) took a new turn. Corder contended that those errors are "important in and of themselves." For learners themselves, errors are indispensable, since the making of errors can be regarded as a device the learner uses in order to learn ${ }^{15}$. It provides evidence of the learner's knowledge of the second language that should be focused as the target language.

This preliminary research aim was to find out the types of errors committed by the first semester students of Arabic Education of IAI DDI Polewali Mandar. The research was limited on the types of grammatical errors and pronunciation committed by the first semester students of Arabic Education of IAI DDI Polewali Mandar during the first meeting of English Subject. The researcher did not analyze all the errors, but was limited to the most frequent

${ }^{11}$ Farhat, S.H., "Error Analysis: A study of the Written Performance of University of Khartoum Freshmen". (Unpublished Thesis; Sudan: Khartoum University, 1994).

${ }^{12}$ Corder, S.P. Error Analysis and Interlanguage, (Oxford: Oxford University, 1981).

${ }^{13}$ Norrish, J., Language Learners and Their Errors, (London: The Macmillan Press, 1983).

${ }^{14}$ Corder, S.P., Error Analysis, (London: Longman, 1974).

${ }^{15}$ Corder, S.P., “The significance of a learner's errors", in IRAL, Vol. 5, No. 4, 1967. 
errors in grammatical committed when the students of the first semester students of Arabic Education when they introduced themselves in English.

\section{Review of Related Literature Criticism of Error Analysis}

According to Hobson, error analysis has been criticised, both from theoretical and methodological point of view. Firstly, in error analysis the norm is the target language and any deviation from the target is viewed as an error. However, determining a norm is problematic because it depends on a variety of factors including the linguistic context, "the medium (spoken or written), the social context (formal or informal), and the relation between speaker and hearer (symmetrical or asymmetrical)'. According to her, deviation from the norm is viewed negatively, which means that these studies do not acknowledge the creative processes learners use in building new language. They, therefore, ignore a large part of the developmental process.

From a methodological point of view, many limitations are discussed in the literature. Firstly, EA measures production (which may be fairly restricted), rather than perception (which may be less restricted). Secondly, EA studies focus on only a small part of the production data (i.e. the error) rather than all the learner language produced. This means that some 'errors' would not appear to be errors because they seem to be well-formed, although they may be misformed from a pragmatic point of view. Furthermore, learners may avoid some of the TL constructions because they do not know how to produce them or because certain structures are perceived as difficult and more likely to induce error. The group that does produce these constructions, albeit with errors, is not directly comparable to the group which avoids the constructions and, therefore, makes fewer errors overall.

Another methodological problem is that the task used to elicit data may have an effect on the errors produced, so that different types and numbers of errors may be produced in different tasks. Errors were also often classified very subjectively and that analysts did not always know enough about languages they were studying to notice subtle but important differences. Analysts did not always correctly identify L1 influence on the learner language since different L1s may influence the source of the error. For example, what is probably a transfer error for a speaker of one language may be simplification error for a speaker of another language. Related to this point is the way in which errors are classified and quantified. Some studies ascribe errors to one source when there could have been more than one source and other studies ascribe errors to several sources when there was only one source. Explanations were often impressionistic and vague. Two or more sources of error were often plausible, yet analysts sometimes opted for just one. This is a criticism taken up who see the root of the problem as a researcher's attempts to describe and classify error simultaneously. First, errors should be described, e.g. by reference to linguistic domain (word order, morphology, lexis, etc or 'surface strategy'(omission, addition, misinformation or misordering). Only then should causes, such as generalization or interference, be attributed.

Another quantification problem occurs when an error is found over a larger linguistic domain than a word. In some cases, one error may create additional errors in a text and it may 
be difficult to decide how to quantify these error forms. Quantification is also problematic since some studies count error types (the occurrence of an error is noted once) and some count tokens (every example of the error is counted). Making comparisons across studies is, therefore, unreliable and comparing error frequencies or generalising the results is not a simple matter.

\section{Error versus mistake}

According to Hobson, at the level of analysis, deciding whether a deviation is an error or a mistake is another problem. Corder contends that mistakes should not be included in the quantification or analysis of errors and this is the approach taken by most analysts ${ }^{16}$. I believe that mistakes can be corrected by the learner, but in practice determining whether a learner cannot correct his or her own deviant utterances is very problematic. Errors occur when the learner does not know the rule and needs to be taught it or when the learner needs to be shown that the wrong knowledge or partial knowledge has been applied to the particular situation. In a different view, Edge rejects this error-mistake classification and calls all deviations from the norm mistakes. These mistakes include:

1. Slips, which are a result of "processing problems or carelessness"

2. Errors, which are comprehensible but which the learner is unable to correct, although the form has been taught, and

3. Attempts, which are fairly incomprehensible and uncorrectable by the learner ${ }^{17}$.

Some researcher argued for two steps in error development. The first step is the presence of errors which the learner does not recognize as errors, and the second step is the presence of errors that the learner recognizes as errors but which he or she cannot correct. The mistake, where the learner is able to correct the wrong form, may be a third step. In other words, mistakes are a performance problem rather than a competence problem ${ }^{18}$, rather like the lapses made by LI speakers. This performance competence distinction is maintained by most theorists in distinguishing errors from mistakes. Another way of determining whether a deviant form should be classified as an error or a mistake is to decide on the gravity of the error. In order to do this, believes that criteria for error gravity need to be established (e.g. 'are lexical errors more serious than grammatical?'), as well as who will judge the gravity (e.g. LI teachers/L2 teachers/non-teachers) ${ }^{19}$. An additional criterion by James is that errors have a lack of speaker intention; otherwise they may be classified as deviances. The classification of an utterance as deviant is further confused by the distinction between unacceptability and ungrammaticality; e.g. a grammatical utterance may be unacceptable because of nonlinguistic factors. Acceptability is judged by use in a particular context, while grammaticality can be judged by a native speaker of the language and a grammatical utterance is necessarily acceptable as well.

\footnotetext{
${ }^{16}$ Corder, S.P., “The significance of a learner's errors", in IRAL, Vol. 5, No. 4, 1967.; Error Analysis, (London: Longman, 1974).; Error Analysis and Interlanguage, (Oxford: Oxford University, 1981).

${ }^{17}$ Edge, Jhon. Mistakes and Correction, (London: Longman. 1989).

${ }^{18}$ Corder, S.P., "The significance of a learner's errors", in IRAL, Vol. 5, No. 4, 1967.

19 James, Karl. Don't Shoot My Dodo on the Resilience on Contrastive and Error Analysis. International Review of Applied Linguistic. Vol 32 No.3 p. 179-200.
} 
Despite the above criticisms and methodological difficulties, there is evidence of a more positive approach to error analysis in some recent writing. According to James there are two reasons for the continued use of error analysis when investigating Second Language data. Firstly, the empirical design is simple, with a clear indication of an error if a particular norm is chosen. Secondly, teachers play this normative role and encourage their students to achieve these target norms. This negative view of error may be held by many teachers, but many second language acquisition theorists tend to regard errors in a more positive way because they regard them as signs of creative hypothesis construction and testing. James feels that those conducting Interlanguage studies and those engaged in Error Analyses have different goals, the former is concerned with developing a theory of acquisition and the latter with pedagogic goals. Cook in Hobson feels that Error Analysis is an effective way of dealing with data in the absence of a suitable analytical framework in Interlanguage studies. An Error Analysis alone does not provide a sufficient description or explanation of learner language, but it has a significant contribution to make as part of an analysis of this type of language because it can offer insights into the sequence of acquisition, the patterns of acquisition and the types of structures which learners find difficult ${ }^{20}$.

\section{Error Analysis}

The field of EA in Second Language Acquisition (SLA) was established in the 1970s by Corder and colleagues. A widely-available survey can be found in chapter eight of Brown's Book ${ }^{21}$. A key finding of EA has been that many learner errors were produced by learners misunderstanding the rules of the new language. EA is a type of linguistic study that focuses on the errors learners make. It consists of a comparison between the errors made in TL and within that TL itself. Corder is the "father" of EA (the EA with the "new look"). It was in his article entitled "The significance of learner errors" that EA took a new turn. Errors used to be "flaws" that needed to be eradicated. Corder presented a completely different point of view. He contended that those errors are "important in and of themselves". In his opinion, systematically analyzing errors made by language learners makes it possible to determine areas that need reinforcement in teaching.

EA emphasizes "the significance of errors in learners' interlanguages system" 22 . The term interlanguages introduced by Selinker refers to the systematic knowledge of an L2 which is independent on both the learner's L1 and the TL. Nemser referred to it as the Approximate System, and Corder as the Idiosyncratic Dialect or Transitional Competence.According to Corder, EA has two objects: one theoretical and another applied. The theoretical object is to understand what and how a learner learns when he studies an L2. The applied object is to enable the learner to learn more efficiently by using the knowledge of his dialect for pedagogical purposes. At the same time, the investigation of errors can serve two purposes, diagnostic (to in-point the problem) and prognostic (to make plans to solve a

${ }^{20}$ Hobson, Allan. Dreaming is Delirium: How the Brain Goes Out, (London: A Bradford Book The MIT Press Cambridge, 1999).

${ }^{21}$ Brown, C., The Interrelation Between Speech Perception and Phonological Acquisition from Infant to Adult, (Great Britain: Blackwell Publishers Limited, 2000).

${ }^{22}$ Brown, D. B., Principles of language learning and teaching, (Third Edition; New Jersey: Prentice Hall, 1994). 
problem). Corder said that it is diagnostic because it can tell us the learner's grasp of a language at any given point during the learning process. It is also prognostic because it can tell the teacher to modify learning materials to meet the learners' problems ${ }^{23}$.

EA research has limitations of providing only a partial picture of learner language; and having a substantive nature in that it does not take into account avoidance strategy in SLA, since EA only investigates what learners do. Learners who avoided the sentence structures which they found difficult due to the differences between their native language and TL may be viewed to have no difficulty. This was pointed out by Brown (1994) and Ellis (1996).

\section{Relevance of Error Analysis in Language Teaching}

Learning a FL is a step-by-step process, during which errors or mistakes are to be expected during this process of learning. Corder states that errors are visible proof that learning is taking place. He has emphasized that errors, if studied systematically, can provide significant insights into how a language is actually learned by a foreigner. He also agrees that studying students' errors of usage has immediate practical application for language teachers ${ }^{24}$.

In his view, errors provide feedback; they tell the teachers something about the effectiveness of his teaching. According to Ancker, making mistakes or errors is a natural process of learning and must be considered as part of cognition ${ }^{25}$.

A prominent researcher of EA is J. C. Richards. In his 1971 book on Perspectives on Second Language Acquisition, he argues that many of the learners' errors happen due to the strategies that they use in language acquisition, especially their L2. The problem includes the reciprocal interference of the target language items; i.e., negative effect of their prior knowledge of their L1 on their absorption of L2. In this situation, EA would allow teachers to figure out on what areas to be focused and what kind of attention is needed in an L2 classroom $^{26}$.

Weireesh also considers learners' errors to be of particular importance because the making of errors is a device the learners' use in order to learn. According to him, EA is a valuable aid to identify and explain difficulties faced by learners. He goes on to say that EA serves as a reliable feedback to design a remedial teaching method ${ }^{27}$.

Sercombe explains that EA serves three purposes. Firstly, to find out the level of language proficiency the learner has reached. Secondly, to obtain information about common difficulties in language learning, and thirdly, to find out how people learn a language ${ }^{28}$.

\footnotetext{
${ }^{23}$ Nemser, W., “Approximate systems of foreign language learners". In Richards, J. (Ed.). Error Analysis: Perspectives on Second Language Acquisition, (Essex: Longman, 1974).

${ }^{24}$ Corder, S.P., "The significance of a learner's errors", in IRAL, Vol. 5, No. 4, 1967.

${ }^{25}$ Ancker, W., "Errors and corrective feedback: Updated theory and classroom practice", English Teaching Forum, Vol. 38, No. 4, 2000.

${ }^{26}$ Richards, J.C., "Social Factors, Interlanguage and Language Learning”, in Richards, J.C. (Ed.) Error analysis. Perspectives on Second Language Acquisition, (London: Longman, 1974).

${ }^{27}$ Weireesh, S., "How to Analyze Interlanguage", Journal of Psychology \& Education, No. 9, 1991.

${ }^{28}$ Sercombe, P. G., "Learner Language and The Consideration of Idiosyncracies By Students of English As A Second of Foreign Language in The Context of Brunei Darul salam", in A.M. Noor et al. (eds.) Strategising Teaching and Learning in The $21^{\text {st }}$ Century, Proceedings of the International Conference on Teaching and Learning, (Bangi: Faculty of Education, Universiti Kebangsaan Malaysia, 2000).
} 
Candling considers EA as "the monitoring and analysis of learner's language". He refers to an error as a deviation. He adds that the L2 learner's errors are potentially important for the understanding of the processes of $\mathrm{SLA}^{29}$.

Olasehinde also argues that it is inevitable that learners make errors. He also cited that errors are unavoidable and a necessary part of the learning curve ${ }^{30}$. Mitchell and Myles claims that errors if studied could reveal a developing system of the students L2 language and this system is dynamic and open to changes and resetting of parameters ${ }^{31}$. This view is supported by Stark in his study, who also explained that the teachers need to view students' errors positively and should not regard them as the learners' failure to grasp the rules and structures but view the errors as process of learning. He subscribes to the view that errors are normal and inevitable features of learning. He added that errors are essential condition of learning ${ }^{32}$.

Vahdatinejad (2008) maintains that error analyses can be used to determine what a learner still needs to be taught. It provides the necessary information about what is lacking in his or her competence. He also makes distinction between errors and lapses (simple mistakes). According to him, lapses are produced even by native speakers, and can be corrected by themselves. They call for on the spot correction rather than remedial, which is needed for errors.

\section{Research Method}

This preliminary research focused on finding out the types of errors committed by the first semester students of Arabic Education of IAI DDI Polewali Mandar. The research subjects are 25 students, 14 male and 11 female students of the first semester of Arabic Education of IAI DDI Polewali Mandar. These research subjects was the source of data. Therefore, in conducting this research, the source of data was the spoken English of self introduction during the English subject. Based on transcription of the spoken English, the researcher analyzed the types of error committed by the students most frequently in grammatical as the main data.

The data were the utterances of spoken English of self introduction during the English subject. The data were collected by taping and recording using a voice recorder and video cameras. The activity in collecting the data lasted for one hour and forty five minutes. The data, then, were transcribed before they were analyzed. And the data were analyzed using error analysis. The analyzing activities were the most frequent error in grammatical. After that the error was done, the researcher analyzed the data. Finally, the researcher interpreted the data in order to answer the research questions.

\footnotetext{
${ }^{29}$ Candling, R. B., Vocabulary and language teaching, (New York: Longman Inc., 2001).

30 Olasehinde, M. O., "Error Analysis and Remedial Pedagogy". In Babatunde S. T. and D. S. Adeyanju (eds.). Language, meaning and society. (Ilorin: Itaytee Press and Publishing Co., Nigeria, 2002).

${ }^{31}$ Mitchell, R. and Myles, M., Second Language Learning Theories, (New York: Hodder Arnold, 2004).

${ }^{32}$ Stark, L., Analyzing The Interlanguage of ASL Natives, (Newark: University of Delaware, 2001).
} 


\section{Findings and Discussions}

\section{Findings}

The examples of errors that have been identified from the spoken English in students' self introduction during English subject of the first semester of Arabic Education of IAI DDI Polewali Mandar could be seen in the table below

\begin{tabular}{|c|c|c|}
\hline I born in Polewali & \multirow{9}{*}{$\begin{array}{c}\text { It } \\
\text { should } \\
\text { be }\end{array}$} & I was born in Polewali \\
\hline I not married & & I $a m$ not married \\
\hline My age twenty six & & My age $\underline{i s}$ twenty six \\
\hline I from Polman & & I am from Polman \\
\hline My hobby swimming and badminton & & $\begin{array}{l}\text { My hobbies are swimming and } \\
\text { badminton }\end{array}$ \\
\hline You can call me is Ira & & You can call me Ira \\
\hline My children four & & My children are four \\
\hline You call me & & You can call me \\
\hline I want to introduce myself ... & & $\begin{array}{l}\text { I want to introduce myself. } \underline{M y} \\
\text { name is / I am }\end{array}$ \\
\hline
\end{tabular}

Table 1: Error in the use of auxilaries

\begin{tabular}{|c|c|c|}
\hline I Study in Islamic Boarding School & \multirow{4}{*}{$\begin{array}{l}\text { It } \\
\text { should } \\
\text { be }\end{array}$} & I study in Islamic Boarding School \\
\hline \multirow{2}{*}{$\begin{array}{l}\text { May be that's my introduce } \\
\text { for introduce myself to you all }\end{array}$} & & I think that's all \\
\hline & & for introducing myself to you all \\
\hline I want introduction myself & & I want to $\underline{t}$ introduce \\
\hline
\end{tabular}

Table 2: Wrong tense formation

I was born Makassar twenty two november two thausand and two

I am graduated in Islamic Boarding

School

I'm graduated from PPM Al Ikhlas

two thousand nineteen

\begin{tabular}{|c|c|}
\hline \multirow{3}{*}{$\begin{array}{c}\text { It } \\
\text { should } \\
\text { be }\end{array}$} & $\begin{array}{l}\text { I was born } \underline{\text { in }} \text { Makassar at twenty } \\
\text { second november in two thousand } \\
\text { and two }\end{array}$ \\
\hline & $\begin{array}{l}\text { I am graduated student of Islamic } \\
\text { Borading School }\end{array}$ \\
\hline & $\begin{array}{l}\text { I'm graduated from PPM Al Ikhlas } \\
\underline{\text { in }} \text { two thousand nineteen }\end{array}$ \\
\hline
\end{tabular}

Table 3: Prepositional error

\begin{tabular}{|c|c|c|}
\hline $\begin{array}{l}\text { Eighteen August two thousand and } \\
\text { two }\end{array}$ & \multirow{7}{*}{$\begin{array}{c}\text { It } \\
\text { should } \\
\text { be }\end{array}$} & $\begin{array}{l}\text { Eighteenth August two thousand } \\
\text { and two }\end{array}$ \\
\hline One Jule & & First Jule \\
\hline Five month & & Fifth May \\
\hline Seventeen seven two thosand & & Seventeen July in two thousand \\
\hline Four december two thousand and two & & $\frac{\text { Fourth December in two thousand }}{\text { and two }}$ \\
\hline One october twc & & First october two thousand and one \\
\hline Six December & & Sixth December \\
\hline
\end{tabular}

Table 4: Error in the use of ordinal and cardinal number 


\begin{tabular}{|l|c|l|}
\hline My married & It & I'm married \\
\cline { 1 - 1 } I husband a teacher & $\underline{M y}$ husband $\underline{i s}$ a teacher \\
\cline { 1 - 1 } I'd like to introduce & be & I'd like to introduce $\underline{\text { myself }}$ \\
\hline
\end{tabular}

Table 5: Pronoun error

\begin{tabular}{|c|c|c|}
\hline $\begin{array}{l}\text { Member children men one women } \\
\text { children two }\end{array}$ & \multirow{5}{*}{$\begin{array}{c}\text { It } \\
\text { should } \\
\text { be }\end{array}$} & I have a son and two daughters \\
\hline I have one husband and one children & & $\begin{array}{l}\text { I'm married and I have a child (I } \\
\text { have a son/a daughter }\end{array}$ \\
\hline I have one boys & & I have a son \\
\hline I'm children three & & $\begin{array}{l}\text { I have three children/My children } \\
\text { are three }\end{array}$ \\
\hline I have children no & & $\begin{array}{l}\text { Idon't have children/I have no } \\
\text { child/children }\end{array}$ \\
\hline
\end{tabular}

Table 6: Plural and singular formation error

\begin{tabular}{|c|c|c|}
\hline Alumni Pesantren & \multirow{5}{*}{$\begin{array}{c}\text { It } \\
\text { should } \\
\text { be }\end{array}$} & $\begin{array}{l}\text { I am graduated student of Islamic } \\
\text { Boarding School }\end{array}$ \\
\hline Sulawesi Barat & & West Sulawesi \\
\hline Sekian mo bu deeh & & That's enough. Thank you \\
\hline Jangan ribut dengarkoe & & Be quiet please, listen to me! \\
\hline Apa itu & & $\begin{array}{l}\text { What is...? How to say..? What is } \\
\text { the English of ...? }\end{array}$ \\
\hline
\end{tabular}

Table 7: Difficult word/phrase/and sentence

\begin{tabular}{|c|l|}
\hline No. & \multicolumn{1}{|c|}{ Most frequently error in pronunciation } \\
\hline 1 & Introduce, Introduction \\
\hline 2 & Graduate, graduated \\
\hline 3 & Born \\
\hline
\end{tabular}

Table 8: Most frequently error in pronunciation

\section{Discussion}

The findings based on the spoken English in students' self introduction during English for English subject of the first semester of Arabic Education of IAI DDI Polewali Mandar committed the following errors: use of auxiliaries, tenses, prepositions, pronouns, plurals, error in pronunciation and some difficult words, phrase, sentence. The conclusion was that Further Education and Training band commits similar errors. With regard to the use of auxiliaries, all students had the tendency of either omitting or over generalising the rule in the use of auxiliaries. Concerning the tense formation the findings revealed that learners were not sure about tense formation. This was seen when they mixed tenses in their spoken English when the students introduced themselves. In as far as the appropriate use of the articles was concerned, the study revealed that some students either used the wrong articles or used them where they were not necessary. The conclusion was that learners did not know where and when to use articles. Learners had a tendency of using the wrong prepositions in their spoken. 
This could probably be attributed to either, the fact that in Bahasa Indonesia students use prepositions in different meanings. The implication was that the meaning and the use of prepositions was not taught to them. Pronoun errors formed part of the findings, since learners could not distinguish between the pronouns 'I' and 'my.' They used them interchangeably. They again tended to use both the noun and the pronoun simultaneously in their sentences. And also in the formation of plural.

\section{Conclusion}

This is a preliminary research to analyze some error committed, they were: the use of auxiliaries, tenses, prepositions, pronouns, plurals, error in pronunciation and some difficult words, phrase, sentence of the spoken English in students' self introduction during English subject of the Arabic Education of IAI DDI Polewali Mandar. The data were used to decided students'needs and abilty of English on preparing the teaching material that were given in the first semester of 2010/2020 academic year. ${ }^{[]}$

\section{References}

Ancker, W., "Errors and corrective feedback: Updated theory and classroom practice", English Teaching Forum, Vol. 38, No. 4, 2000.

Belhaj, A.M., "Contrastive Textual Analysis: An Arabic-English, English-Arabic Translation Corpus". Occasional Papers, Vol. 24-25, 1997.

Brown, D. B., Principles of language learning and teaching, third edition; New Jersey: Prentice Hall, 1994.

Brown, C., The Interrelation Between Speech Perception and Phonological Acquisition from Infant to Adult, Great Britain: Blackwell Publishers Limited, 2000.

Candling, R. B., Vocabulary and language teaching, New York: Longman Inc., 2001.

Corder, S.P., "The significance of a learner's errors", in IRAL, Vol. 5, No. 4, 1967.

, Error Analysis, London: Longman, 1974.

, Error Analysis and Interlanguage, Oxford: Oxford University, 1981.

Dessouky, S.S., "Error Analysis: A no-stop Area of Research. An Analytical Study of English Verb and Preposition Errors in the Written Expression of Al-Azhar Students". Studies in Curricula and Methodology, No. 8, July, 1990.

Edge, Jhon. Mistakes and Correction. London: Longman. 1989.

Ellis, R., Second Language Acquisition Research and Language Teaching, Oxford: Oxford University Press, 1996.

El-Sayed, A.M.M., “An Investigation into the Syntactic Errors of Saudi Freshmen's English Compositions”. Unpublished Dissertation; USA: Indiana University of Pennsylvania, 1982.

Farhat, S.H., "Error Analysis: A study of the Written Performance of University of Khartoum Freshmen". Unpublished Thesis; Sudan: Khartoum University, 1994.

Hobson, Allan. Dreaming is Delirium: How the Brain Goes Out. London: A Bradford Book The MIT Press Cambridge. 1999. 
James, Karl. Don't Shoot My Dodo on the Resilience on Contrastive and Error Analysis. International Review of Applied Linguistic. Vol 32 No.3 p. 179-200.

Karma, N. and Hajjaj, H., Errors in English among Arabic Speakers Analysis and Remedy, London: Longman, 1989.

Michaelides, N.N., "Error Analysis: An Aid to teaching", English Teaching Forum, Vol. XXXVIII, No. 4, 1990.

Mitchell, R. and Myles, M., Second language learning theories, New York: Hodder Arnold, 2004.

Nemser, W., “Approximate systems of foreign language learners". In Richards, J. (Ed.). Error Analysis: Perspectives on Second Language Acquisition. Essex: Longman, 1974.

Norrish, J., Language Learners and Their Errors, London: The Macmillan Press, 1983.

Olasehinde, M. O., "Error Analysis and Remedial Pedagogy". In Babatunde S. T. and D. S. Adeyanju (eds.). Language, meaning and society. Ilorin: Itaytee Press and Publishing Co., Nigeria, 2002.

Radwan, M.A., "A linguistic analysis of the grammatical and Lexical Errors in the Nominal Group Found in the Written English of Syrian University Students". Unpublished Dissertation; UK: University of Nottingham, 1988.

Richards, J.C., "Social Factors, Interlanguage and Language Learning", in Richards, J.C. (Ed.) Error analysis. Perspectives on Second Language Acquisition, London: Longman, 1974.

Scott, M. S. and Tucker, G.R., "Error Analysis and English-Language Strategies of Arab Students". Language Learning, Vol. 24, No. 1, 1974.

Sercombe, P. G., "Learner Language and The Consideration of Idiosyncracies By Students of English As A Second of Foreign Language in The Context of Brunei Darulsalam", in A.M. Noor et al. (eds.) Strategising Teaching and Learning in The $21^{\text {st }}$ Century, Proceedings of the International Conference on Teaching and Learning, Bangi: Faculty of Education, Universiti Kebangsaan Malaysia, 2000.

Stark, L., Analyzing The Interlanguage of ASL Natives, Newark: University of Delaware, 2001.

Weireesh, S., "How to Analyze Interlanguage", Journal of Psychology \& Education, No. 9, 1991.

Willcott, P.J., "An Analysis of The Written English of Native Speakers of Arabic As Found in American History Final Examination Given at The University of Texas at Austin", Unpublished Dissertation; USA: The University of Texas at Austin, 1972. ${ }^{[]}$ 